\title{
Evaluation of Atmospheric Correction Algorithms for Landsat-8 OLI and MODIS-Aqua to Study Sediment Dynamics in the Northern Gulf of Mexico
}

\author{
Nazanin Chaichitehrani ${ }^{1}{ }^{*}$, Erin Lee Hestir ${ }^{2}$, Chunyan Li ${ }^{1}$ \\ ${ }^{1}$ Department of Oceanography \& Coastal Sciences, Louisiana State University, Baton Rouge, USA \\ ${ }^{2}$ School of Engineering, University of California, Merced, USA \\ Email: *nchaichi@gmail.com
}

How to cite this paper: Chaichitehrani, N., Hestir, E.L. and Li, C.Y. (2018) Evaluation of Atmospheric Correction Algorithms for Landsat-8 OLI and MODIS-Aqua to Study Sediment Dynamics in the Northern Gulf of Mexico. Advances in Remote Sensing, 7, 101-124.

https://doi.org/10.4236/ars.2018.72008

Received: April 21, 2018

Accepted: June 19, 2018

Published: June 22, 2018

Copyright $\odot 2018$ by authors and Scientific Research Publishing Inc. This work is licensed under the Creative Commons Attribution International License (CC BY 4.0).

http://creativecommons.org/licenses/by/4.0/

(c)

\begin{abstract}
Suspended particulate matter (SPM) is regarded as an energy source and a water quality indicator in coastal and marine ecosystems. To estimate SPM from ocean color sensors and land observing satellites, an accurate and robust atmospheric correction must be done. We evaluated the capabilities of ocean color and land observing satellite for estimation of SPM concentrations over Louisiana continental shelf in the northern Gulf of Mexico, using the Operational Land Imager (OLI) on Landsat-8, and Moderate Resolution Imaging Spectroradiometer (MODIS) on Aqua. In high turbidity waters, the traditional atmospheric correction algorithms based on near-infrared (NIR) bands underestimate SPM concentrations due to the inaccurate removal of the aerosol contribution to the top of atmosphere signals. Therefore, atmospheric correction in high turbidity waters is a challenge. Four atmospheric correction algorithms were implemented on remote sensing reflectance (Rrs) values to select suitable atmospheric correction algorithms for each sensor in our study area. We evaluated short-wave infrared (SWIR) and NIR atmospheric correction algorithms on Rrs products from Landsat-8 OLI and Management Unit of the North Sea Mathematical Models (MUMM) and SWIR.NIR atmospheric correction algorithms on Rrs products from MODIS-Aqua. SPM was retrieved from a band-ratio SPM-retrieval algorithm for each sensor. Our results indicated that SWIR atmospheric correction algorithm was the suitable algorithm for Landsat-8 OLI and SWIR.NIR atmospheric correction algorithm outperformed MUMM algorithm for MODIS.
\end{abstract}

\section{Keywords}

Suspended Particulate Matter, Remote Sensing, Atmospheric Correction 
Algorithms, River Plume

\section{Introduction}

Suspended particulate matter (SPM) plays a major role in the biological and ecological status of inland, coastal, and shelf waters, and can cause detrimental effects on marine ecosystems [1] [2] [3] and has a strong influence on the phytoplankton productivity and abundance by changing photosynthetically active radiation (PAR) and euphotic depth [4]. To understand the influence of SPM on water quality impairment and nutrient availability in coastal waters and river plumes, it is imperative to study the temporal and spatial dynamics of SPM. The traditional method of monitoring SPM using ship and platform measurements is limited in spatial coverage, and it can be difficult to maintain regular monitoring programs for time-series assessments. However, with the advent of satellite-based sensors and computer simulation packages, some studies on SPM dynamics with a high spatial and temporal resolution have been done [5] [6] [7]. A well-calibrated and validated sediment transport model along with a reliable satellite-derived SPM data can provide spatially continuous near-surface maps of SPM. Among ocean color sensors and land imagers, the capability of Landsat-8, Operational Land Imager (OLI) and Aqua, Moderate Resolution Imaging Spectroradiometer (MODIS) to estimate SPM in coastal waters have been proven [8] [9] [10]. Landsat-8 was launched on February 11, 2013 and started operating on May 30, 2013. It has 11 spectral bands $(433-12,500 \mathrm{~nm})$, spatial resolutions of $30 \mathrm{~m}$ and $15 \mathrm{~m}$ in the panchromatic band, and a revisit time of 16 days. The high signal-to-noise ratio (SNR), the 12-bit quantization combined with $30 \mathrm{~m}$ spatial resolution of the Landsat-8 OLI enhance our ability to monitor SPM dynamics in coastal waters [11] [12]. Landsat-8 OLI spatial resolution is sufficient to resolve SPM plume and to provide a map of the well-defined turbidity plume from the Mississippi River (Figure 1). However, with a designed revisit time of 16-days and an effective revisit time of c.a. seasonal when cloud cover is taken into account [13], Landsat's temporal resolution is highly limited for studying the SPM dynamics over regions with the high sediment dynamics regime.

The area around the Mississippi River delta, particularly during extreme meteorological events is an example of such a dynamics region [14]-[20]. Thus, a sampling revisit time of daily or better is optimal for resolving the effects of such dominant events in this area. MODIS on the Aqua satellite with a revisit time of one day can overcome this shortcoming. MODIS is an ocean color sensor on the Aqua satellite launched on May 4, 2002. MODIS-Aqua has 36 spectral bands with spatial resolutions of $250 \mathrm{~m}, 500 \mathrm{~m}$, and $1 \mathrm{~km}$ and temporal resolution of one image per day, which provides a wealth of information about the biological and physical properties of the ocean. The temporal resolution (daily) of MODIS-Aqua enables observations of the daily dynamics of SPM around the 


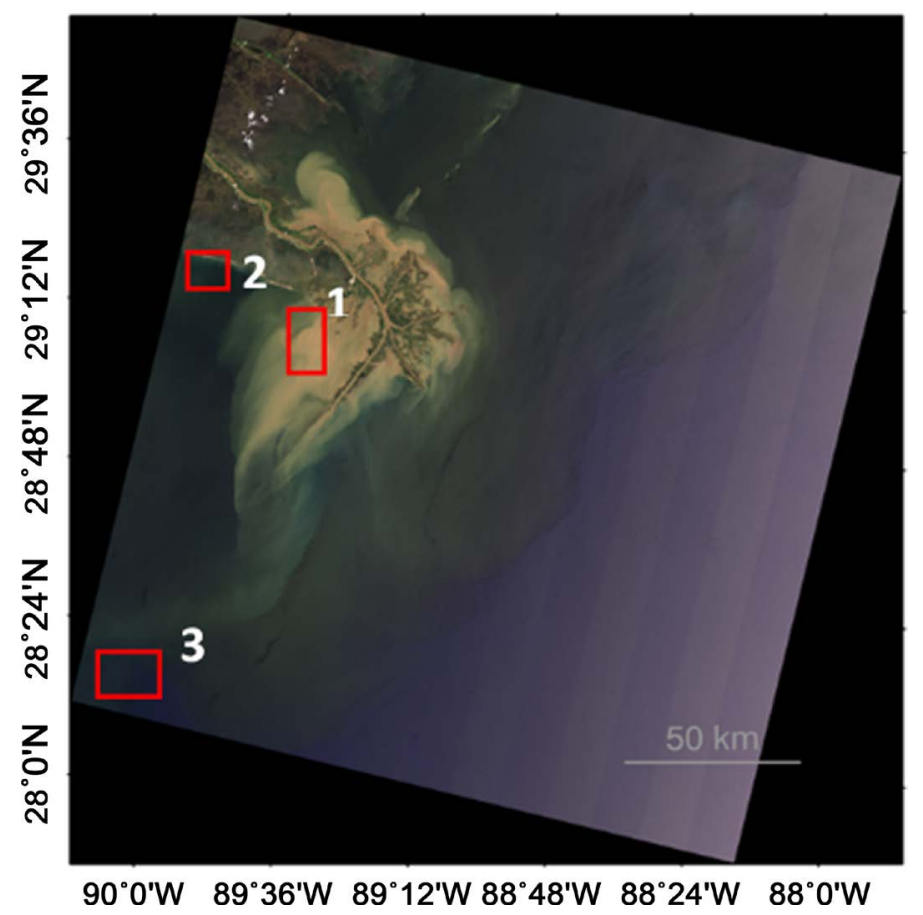

Figure 1. Rayleigh-corrected Landsat-8 OLI image over the Mississippi River plume, coastal water and Lousiana continental shelf waters on 23 April 2016 representing high turbidity waters around the Mississippi River' passes and coastal waters as well as the dispersion of sediment-rich water to offshore waters. Box 1, box 2 and box 3 represent high, moderate and low turbidity water.

Mississippi River plume. Thus, to study sediment dynamics Landsat-8 OLI and MODIS-Aqua should be used in tandem in our study region partiality during extreme meteorological events. SPM is retrieved from satellite data by relating its concentration to apparent optical properties (AOPs) (e.g., empirical algorithms) and inherent optical properties (IOPs) (e.g., semi-analytical and analytical algorithms) in high and in low to moderate turbid waters (Case-II and Case-I, respectively) [8] [21] [22] [23] [24].

Several studies have used remote sensing reflectance products in red and green wavelengths to estimate SPM concentration in Case-I waters from ocean color sensors (e.g., SeaWiFS, MODIS, MERIS) and land imagers (e.g., Landsat ETM/OLI) [8] [23] [25] [26]. However, several studies have shown that as the SPM concentration increases, the remote sensing signal saturates at short wavelengths (blue, green) and then eventually in red band and even in the nearinfrared (NIR) band in Case-II waters, and becomes less sensitive to increases in SPM concentration [10] [11] [27] [28]. The increase in reflectance caused by increased SPM concentration in Case II turbid coastal waters necessitates not only careful selection of SPM retrieval algorithms, but also necessitates adaptation of atmospheric correction algorithms [9] [29]. The pioneering atmospheric correction algorithm was developed for the global Case-I waters using MODIS's two NIR bands (748 - $869 \mathrm{~nm})$. This method assumes that in clear water the NIR water-leaving radiance contributions to the top of atmosphere (TOA) signal is 
negligible, and any measured signal is due to aerosol scattering [30] [31]. Hence, NIR atmospheric correction algorithms for SPM retrieval in high turbidity waters can lead to an overestimation of aerosol reflectance and an underestimation of SPM concentration [32]. While it has been shown that short-wave infrared (SWIR) atmospheric correction algorithms can perform well in high turbid coastal waters [33] [34]. In recognition of difficulties for selecting the most effective atmospheric correction methods in high turbidity water, developing of atmospheric correction models based on the combination of NIR and SWIR bands or two SWIR bands has gained increased attention [12] [34] [35] [36] [37]. Ody et al. [10] evaluated NIR and SWIR atmospheric correction for Landsat-8 and Management Unit of the North Sea Mathematical Models (MUMM) and NIR-SWIR for MODIS attempting to study the sediment dynamics in Rhone River plume.

The main objective of this paper is to evaluate different atmospheric correction methods for three study areas covering high to low turbidity waters in the northern Gulf of Mexico and an aim to develop SPM maps that can be used to evaluate sediment transport models was made. Accurate maps of SPM can also be used as indicators of coastal dynamics to improve our understanding of coastal zone hydrodynamics and to help prioritize sampling locations and field surveying times. Furthermore, daily MODIS-derived SPM can be used as an initial condition input in sediment transport and ecosystem models.

To the best of our knowledge, no study has yet been undertaken to test or evaluate atmospheric correction algorithms performance using Landsat-8 OLI and MODIS-Aqua for retrieval of SPM in the northern Gulf of Mexico coastal and shelf waters.

\section{Methods}

The overarching goal of this study is to estimate SPM concentration using Landsat-8 OLI and MODIS-Aqua. To achieve this goal, the following steps should be performed:

1) Identify the most appropriate and suitable atmospheric correction methods across high- to low-turbidity waters.

2) Apply a standard SPM retrieval algorithm [23] across all corrected datasets.

3) Compare retrieved SPM concentration with in situ-measured SPM concentration.

\subsection{Study Area}

The study area covers the northern Gulf of Mexico with the focus on the west flank of the Mississippi River. The Mississippi River ranks as the seventh largest system in the world in terms of discharge and sediment load [38] [39], with a mean freshwater discharge of $1.35 \pm 0.2 \times 10^{4} \mathrm{~m}^{3} \cdot \mathrm{s}^{-1}$ [40], and transporting about 230 million tons of sediment to the Gulf of Mexico annually [41]. The sedimentand nutrient-laden fresh water from the Mississippi River plume influence the 
primary productivity and fishery activities in the northern Gulf of Mexico [14] [42] [43] [44].

The SPM dynamics around the Mississippi River delta is optically complex and variable in time and space. Sediment resuspension as a geomorphic response to extreme weather events (e.g., hurricanes and cold fronts) contributes to the turbidity and the complexity of the Mississippi River delta and coastal waters in the northern Gulf of Mexico. Figure 1 presents a Rayleigh-corrected RGB Landsat-8 OLI image over the Mississippi River plume on 23 April 2016 showing turbid coastal waters with high sediment concentration (yellow-brown) around the Mississippi River passes, as well as the extension of sediment-laden waters to the Lousiana continental shelf.

This true color satellite image shows a distinct dispersal pattern of turbidity into the Gulf of Mexico and coastal areas around the Mississippi River passes. The Mississippi River tends to direct the plume to the northwest during fall and winter and to the east during spring and summer [5] [7] [45] [46] [47] [48] [49]. Wind-generated currents and waves are the most important geological agents controlling sediment dynamics over the Louisiana continental shelf [5].

To investigate the performance of atmospheric correction algorithms and to select the most appropriate approaches in our study area, our study area was divided into three regions ranging from high-to-low turbidity (Figure 1).

These three regions were selected based on the distance from the Mississippi River passes (e.g., Southwest Pass) as well as assessing true color images obtained from different time periods. Box 1 is in the vicinity of the Mississippi River passes and encompasses the high turbidity water. This region is highly influenced by the Mississippi River sediment plume. Box 2 encloses the moderate turbid water, and this region is relatively far from the Mississippi River passes. This region is influenced by tidal-induced transport of suspended sediment from the Barataria Bay (see Figure 2 for location). Box 3 surrounds the low turbid water, which is far from the Mississippi River plume (Figure 1).

\subsection{Landsat-8 OLI Data Collection and Atmospheric Correction}

In this study, the remote sensing reflectance (Rrs) at $443 \mathrm{~nm}$ (coastal/aerosol), $483 \mathrm{~nm}$ (blue), $560 \mathrm{~nm}$ (green), $655 \mathrm{~nm}$ (red), $864 \mathrm{~nm}$ (NIR) and two SWIR bands at $1601 \mathrm{~nm}$ and $2380 \mathrm{~nm}$ were used in atmospheric correction algorithms and the subsequent SPM retrieval algorithm. Two atmospheric correction approaches were applied to the Landsat-8 OLI data, ACOLITE-NIR and ACOLITE-SWIR.

Two orthorectified and terrain corrected Landsat-8 OLI Level $1 \mathrm{~T}$ images in GeoTIFF format were obtained from U.S. Geological Survey (USGS) Earth Explorer portal (https://earthexplorer.usgs.gov/) for the northern Gulf of Mexico (Path: 21; Row: 40). Since a high Mississippi River flow peak typically occurs in the spring, the Landsat-8 OLI cloud-free image on 23 April 2016 was acquired to test the performance of the atmospheric correction algorithms. Additionally, based on available in situ SPM concentration measurements [50] Landsat-8 OLI 


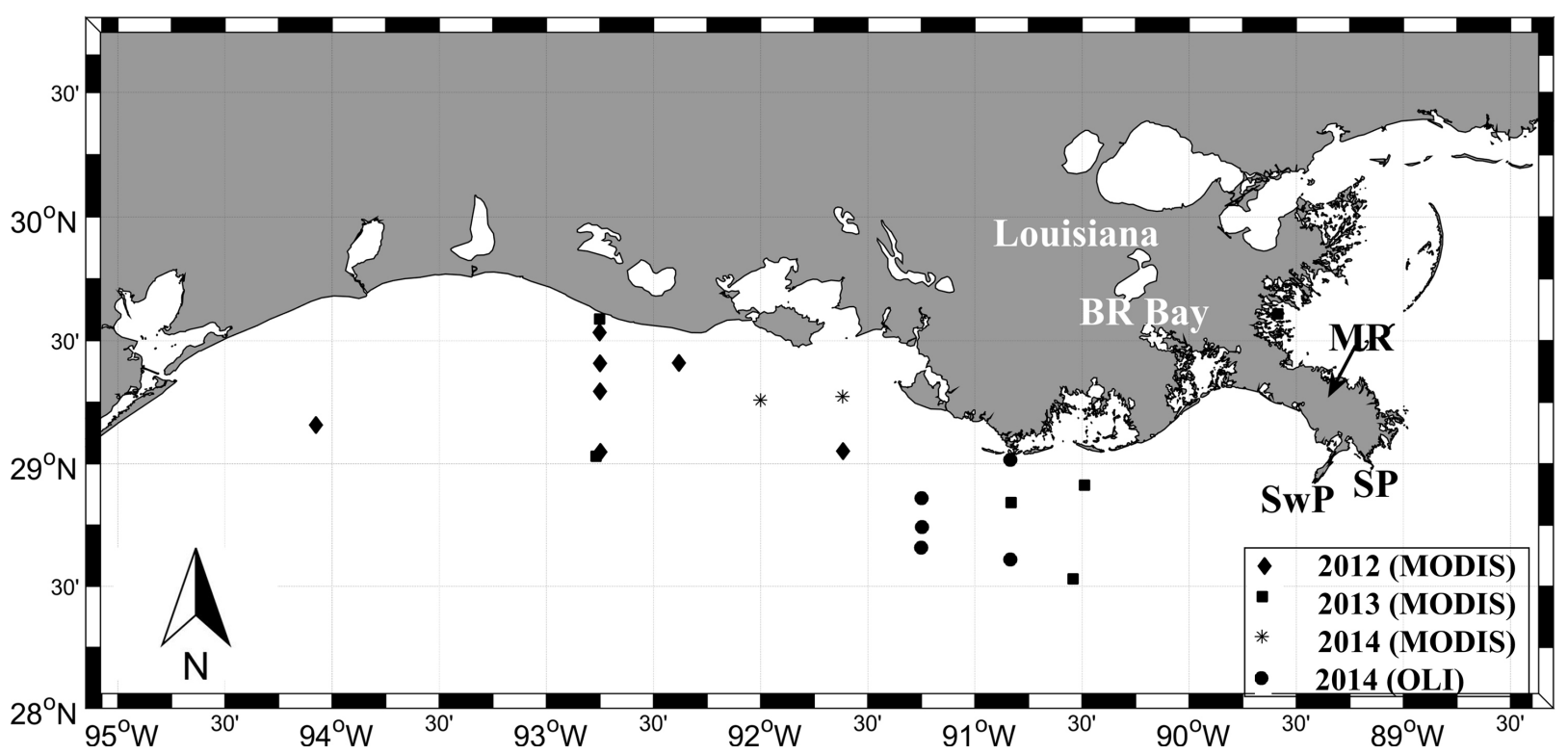

Figure 2. Map of our study area and the location of stations used to perform the match-ups between Landsat-8 OLI-, MODIS-derived SPM concentrations and in situ SPM concentrations (see Table 1 for detail). The geographic location of the Barataria Bay, the Mississippi River, Southwest Pass, and South Pass labeled as BR Bay, MR, SwP, and SP, respectively.

Table 1. Summary of data sets used in match-up comparisons between in situ and OLI-, MODIS-derived SPM.

\begin{tabular}{ccc}
\hline Date & Satellite & Reference \\
\hline 25-27 July 2012 & MODIS-Aqua & {$[54]$} \\
8 March 2013 & MODIS-Aqua & {$[55]$} \\
13 June 2013 & MODIS-Aqua & {$[55]$} \\
23 July 2013 & MODIS-Aqua & {$[55]$} \\
13-14 September 2013 & MODIS-Aqua & {$[53]$} \\
30 July 2014 & MODIS-Aqua and Landsat-8 OLI & {$[50]$} \\
\hline
\end{tabular}

data was obtained on 30 July 2014 (Table 1). Table 2 provides Landsat-8 OLI spectral bands, SNR and corresponding spatial resolution used in this study.

The ACOLITE (version 20170718.0) software package

(https://odnature.naturalsciences.be/remsem/software-and-data/acolite) was used to obtain atmospherically corrected remote sensing reflectance products [9] [12]. ACOLITE is an atmospheric correction and processor for the Landsat-8, and Sentinel-2A (S2A) MultiSpectral Imager (MSI) developed at the Royal Belgian Institute of Natural Science (RBINS).

Two following embedded atmospheric correction algorithms in ACOLITE were applied to Landsat-8 OLI data: 1) The NIR algorithm using the red (655 $\mathrm{nm}$ ) and NIR (865 $\mathrm{nm}$ ) bands [9] based on the MUMM [32]; 2) The SWIR algorithm using two high-quality SWIR bands at $1609 \mathrm{~nm}$ (SWIR I) and $2201 \mathrm{~nm}$ (SWIR II) [9] [51]. 
Table 2. Landsat-8 OLI and MODIS-Aqua's band specifications used in this study.

\begin{tabular}{ccccc}
\hline Sensor/Satellite & Band Number & Central band $(\mathrm{nm})$ & SNR at reference $\mathrm{L}_{\text {typ }}$ & Spatial Resolution $(\mathrm{m})$ \\
\hline & 1 & 443 & 237 & 30 \\
Landsat-8 OLI & 4 & 483 & 367 & 30 \\
& 4 & 561 & 304 & 30 \\
& 5 & 655 & 227 & 30 \\
& 6 & 865 & 201 & 30 \\
& 7 & 1609 & 267 & 30 \\
& 9 & 2201 & 327 & 30 \\
& 10 & 443 & 2253 & 1000 \\
& 4 & 488 & 2270 & 1000 \\
& 14 & 555 & 349 & 500 \\
MODIS-Aqua & 678 & 2175 & 1000 \\
& 15 & 748 & 1371 & 1000 \\
& 16 & 869 & 1112 & 1000 \\
& 5 & 1240 & 25 & 500 \\
& 7 & 2130 & 12 & 500 \\
\hline
\end{tabular}

\subsection{MODIS-Aqua Data Collection and Atmospheric Correction}

MODIS-Aqua Level-1A data were downloaded from NASA Ocean Color website (https://oceancolor.gsfc.nasa.gov) (Table 1). The Level-1 A data were processed and was upgraded to Level 1B using SeaDAS (version 7.4.). The SeaDAS package has been developed and distributed by NASA's Ocean Biology Processing Group. Level-2 remote sensing reflectance at $443,488,555$, and $678 \mathrm{~nm}$ were generated by applying MUMM [32] and SWIR.NIR atmospheric correction algorithms (Wang and Shi 2007; Wang, Son, and Shi 2009) [34] [37] using the l2gen function.

The MUMM correction used two MODIS NIR bands at $748 \mathrm{~nm}$ and $869 \mathrm{~nm}$. The SWIR.NIR correction was applied using two MODIS NIR bands at $748 \mathrm{~nm}$ and $869 \mathrm{~nm}$ and two SWIR bands at $1240 \mathrm{~nm}$ and $2130 \mathrm{~nm}$. All Rrs products were generated at a resolution of $1 \mathrm{~km}$. Table 2 summarises the MODIS-Aqua bands used in this study.

\subsection{SPM Retrieval Algorithm}

The atmospherically corrected remote sensing reflectance products were used in a regional SPM-retrieval algorithm [23] to estimate SPM concentration from Landsat-8 OLI and MODIS-Aqua. Reference [23] developed a regional two-band (green-to-red) empirical algorithm to estimate SPM in the northern Gulf of Mexico from SeaWiFS (Equation (1)). The SPM concentration retrieval algorithm [23] was developed using in situ remote sensing reflectance in red (670 $\mathrm{nm})$ and green $(555 \mathrm{~nm})$ and was calibrated with in situ measurements. This al- 
gorithm performed better, and the errors were minimized compared to the previous single-band SPM retrieval algorithm in the northern Gulf of Mexico [8].

In addition, the use of band $(670 \mathrm{~nm})$ closest to NIR bands makes this algorithm more robust than other visible single-band algorithms [8]. This algorithm is the only available band-ratio algorithm designed to estimate SPM concentration (mg. $1^{-1}$ ) from SeaWIFS in the northern Gulf of Mexico, but in this study the lack of in situ Rrs led us to adjust and modify this algorithm based on closest available bands in Landsat-8 OLI and MODIS-Aqua. Remote sensing reflectance products were replaced with the closest available wavelengths in Landsat-8 OLI $(560 \mathrm{~nm}$ and $655 \mathrm{~nm}$ ) and MODIS-Aqua (555 nm and $678 \mathrm{~nm}$ ). The algorithm was applied to the atmospherically corrected remote sensing reflectance products from Landsat-8 OLI and MODIS-Aqua.

$$
S P M=17.783\left(\frac{\operatorname{Rrs} 670}{\operatorname{Rrs} 555}\right)^{1.11}
$$

where $S P M$ is the suspended particulate matter concentration in (mg. $\mathrm{l}^{-1)}$ and Rrs are the remote sensing reflectance in $\left(\mathrm{sr}^{-1}\right)$.

\subsection{In Situ SPM Measurements}

To validate Landsat-8 OLI-derived SPM concentrations, in situ SPM concentrations (Figure 2, Table 1) measured on 30 July 2014 were used [50]. The time difference of $\pm 3 \mathrm{hr}$ between SPM measurements and Landsat-8 OLI overpass was considered [52]. MODIS-estimated SPM concentrations were validated using the SPM concentrations measurements provided by NASA SeaWiFS Biooptical Archive and Storage System (SeaBASS) [53] and by NOAA National Centers for Environmental Information (NCEI) [50] [54] [55]. The in situ SPM dataset collected in July 2012, March, June, July, September 2013, and July 2014 matched-up with MODIS-derived SPM concentrations (Figure 2, Table 1). The time difference between SPM measurements and MODIS-Aqua overpasses used in the validation was constrained to $\pm 3 \mathrm{hr}$ [52]

\section{Results and Discussion}

\subsection{Landsat-8 0LI}

\subsubsection{Comparison of Atmospheric Correction Approaches}

The Landsat- 8 OLI remote sensing reflectance products at 443, 483, 561 and 655 $\mathrm{nm}$ bands were corrected for atmospheric effects using ACOLITE SWIR and NIR. The remote sensing reflectance products at $443 \mathrm{~nm}, 483 \mathrm{~nm}, 561 \mathrm{~nm}$, and $655 \mathrm{~nm}$ from ACOLITE SWIR algorithm were compared against the ACOLITE NIR results. Table 3 summarizes the $5^{\text {th }}, 95^{\text {th }}$ percentile, the percentage difference (Equation (2)), the median ratio (NIR to SWIR) and the semi-interquartile range (SIQR) values (Equation (3)) of the SWIR- and NIR-corrected Rrs in high to low turbid waters (box1, box 2 and box3). The SIQR measures the spread of the data [52] 


$$
\begin{aligned}
& \frac{\frac{|S W I R-N I R|}{S W I R+N I R}}{2} \times 100 \\
& \text { SIRQ }=\frac{Q_{3}-Q_{1}}{2}
\end{aligned}
$$

where $Q_{1}$ is the $25^{\text {th }}$ percentile and $Q_{3}$ is the $75^{\text {th }}$ percentile.

The $5^{\text {th }}$ percentile of the SWIR- and NIR-corrected Rrs at $483 \mathrm{~nm}$ were respectively $\sim 0.0110 \mathrm{sr}^{-1}$ and $\sim 0.010 \mathrm{sr}^{-1}$ and the $95^{\text {th }}$ percentile of the SWIR- and NIR-corrected Rrs were respectively $\sim 0.0171 \mathrm{sr}^{-1}$ and $\sim 0.0140 \mathrm{sr}^{-1}$ in high-turbidity waters (box 1 ) followed by $20.5 \%$ difference (Table 3 ).

The percentage difference decreased to 16.6 in box 3 at $483 \mathrm{~nm}$. In the red band $(655 \mathrm{~nm})$, the percentage difference between Rrs corrected by SWIR and NIR approaches was $33.18 \%$ in high turbidity waters and $15.0 \%$ in moderately turbid waters. In box 1, The NIR atmospheric correction algorithm retrieved negative or NAN Rrs values that were not included in match-ups.

The SWIR-corrected Rrs products had higher values compared to the NIR-corrected Rrs products. The maximum percentage difference (33.18\%) was observed in box 1 (high turbid waters) at $655 \mathrm{~nm}$. The computed percentage differences suggested that the difference between the SWIR- and NIR-corrected Rrs at each wavelength increased as the turbidity increased.

The observed percentage difference between SWIR-and NIR-corrected Rrs values in high turbidity water could be due to the fact that the NIR-correction is only adapted to low to moderately turbid waters. The atmospherically corrected Rrs products using SWIR and NIR approaches were plotted and color-coded based on the distance $(\mathrm{km})$ from the Southwest Pass (see Figure 2 for location)

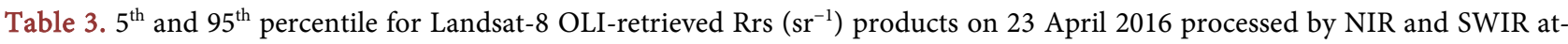
mospheric correction algorithms, the percentage difference, median NIR to SWIR ratio, and SIQR in box 1, 2 and 3.

\begin{tabular}{cccccccc}
\hline Band & Box & $\begin{array}{c}5^{\text {th }} \text { percentile } \\
\text { SWIR approach }\end{array}$ & $\begin{array}{c}95^{\text {th }} \text { percentile } \\
\text { SWIR approach }\end{array}$ & $\begin{array}{c}5^{\text {th }} \text { percentile } \\
\text { NIR approach }\end{array}$ & $\begin{array}{c}\text { 95 } 5^{\text {th }} \text { percentile } \\
\text { NIR approach }\end{array}$ & $\begin{array}{c}\text { Percentage } \\
\text { Difference }\end{array}$ & $\begin{array}{c}\text { Median } \\
\text { Ratio (SIQR) }\end{array}$ \\
\hline \multirow{2}{*}{$443 \mathrm{~nm}$} & 1 & 0.0066 & 0.0117 & 0.0052 & 0.0097 & 14.50 & $0.930( \pm 0.110)$ \\
& 2 & 0.0035 & 0.0058 & 0.0032 & 0.0056 & 12.80 & $0.928( \pm 0.102)$ \\
& 3 & 0.0024 & 0.0039 & 0.0019 & 0.0033 & 9.09 & $0.917( \pm 0.058)$ \\
$483 \mathrm{~nm}$ & 1 & 0.0110 & 0.0171 & 0.0100 & 0.0140 & 20.49 & $0.959( \pm 0.067)$ \\
& 2 & 0.0047 & 0.0072 & 0.0046 & 0.0071 & 17.28 & $0.953( \pm 0.069)$ \\
& 1 & 0.0034 & 0.0048 & 0.0031 & 0.0043 & 16.60 & $0.945( \pm 0.041)$ \\
$561 \mathrm{~nm}$ & 2 & 0.0185 & 0.0265 & 0.0184 & 0.0240 & 14.73 & $0.978( \pm 0.039)$ \\
& 3 & 0.0046 & 0.0079 & 0.0044 & 0.0076 & 14.06 & $0.969( \pm 0.057)$ \\
& 1 & 0.0026 & 0.0040 & 0.0024 & 0.0036 & 13.20 & $0.934( \pm 0.057)$ \\
$655 \mathrm{~nm}$ & 2 & 0.0025 & 0.0320 & 0.0160 & 0.0280 & 33.18 & $0.982( \pm 0.031)$ \\
& 3 & 0.0014 & 0.0049 & 0.0024 & 0.0045 & 15.00 & $0.948( \pm 0.078)$ \\
& & 0.0025 & 0.0013 & 0.0022 & 14.24 & $0.894( \pm 0.107)$ \\
\hline
\end{tabular}


$\left(28^{\circ} 54^{\prime} 18^{\prime \prime} \mathrm{N} 89^{\circ} 25^{\prime} 42^{\prime \prime W}\right)$ (Figure 3, left panel) and SPM concentrations (mg. $\mathrm{l}^{-1}$ ) (Figure 3, right panel). The hydrodynamics around the Mississippi River plume is very complex, and sediment flux from the River is not restricted to any specific outlet. Figure 3 left panel shows the Rrs signal increased as the distance from the Southwest Pass decreased and the SPM concentrations increased. The linear relationship between corrected Rrs products was observed in band 1 through 4 , while as the turbidity started increasing (moving toward box 1) the linear relationship failed as the data deviated from 1:1. Figures 3(a)-(d) shows that remote sensing reflectance values at $443 \mathrm{~nm}$ and $483 \mathrm{~nm}$ increased as the water became more turbid and the data were strikingly pulled down from 1:1. Furthermore, Figures 3(a)-(d) depicts that the short wavelengths (443 nm: aerosol band and $483 \mathrm{~nm}$ : blue bands) are highly sensitive to increase in SPM concentration $\left(\mathrm{mg} \cdot \mathrm{l}^{-1}\right)$ compared to green $(561 \mathrm{~nm})$ and red $(655 \mathrm{~nm})$ bands.

The best agreement was obtained between SWIR-and NIR-corrected Rrs at $655 \mathrm{~nm}$ (slope $=0.92, \mathrm{R}^{2}=0.98$ ), and the lowest agreement was observed at between SWIR and NIR corrected Rrs at $443 \mathrm{~nm}$ (slope $=0.53$ and $\mathrm{R}^{2}=0.46$ ) for all data points located in three boxes (Figure 3(a) and Figure 3(c)). Table 4 presents computed statistical parameters including BIAS, root mean square error (RMSE), scatter index (SI), Willmott Index (WI) (Equation (4)) and the coefficient of determination $\left(\mathrm{R}^{2}\right)$ for Landsat-8 OLI Rrs products processed by NIR and SWIR atmospheric correction algorithms. The Willmott Index presented by [56] as:

$$
d=1-\frac{\sum_{j=1}^{n}[y(j)-x(j)]^{2}}{\sum_{j=1}^{n}[|y(j)-\bar{y}|+|x(j)-\bar{x}|]^{2}}
$$

where $x(j)$ are measured values, $\mathrm{y}(j)$ are simulated values, and $\bar{x}$ and $\bar{y}$ represent the mean values of measurement and simulation, respectively. Index values vary between 0 for poor agreement and 1 for a perfect match. As turbidity increases, the agreement between corrected Rrs products using NIR and SWIR algorithms decreased (Table 4). The non-linear relationship was pronounced for Rrs values larger than $0.009 \mathrm{sr}^{-1}$ at $443 \mathrm{~nm}$ and greater than $0.015 \mathrm{sr}^{-1}$ at $483 \mathrm{~nm}$ where the NIR algorithm retrieved lower Rrs values than the SWIR algorithm (Figures 3(a)-(d)). The linear relationship between SWIR and NIR corrected Rrs at $655 \mathrm{~nm}$ observed for the values of Rrs smaller than $\sim 0.027 \mathrm{sr}^{-1}$ and the SPM concentrations lower than $\sim 20 \mathrm{mg}^{-1}$ in low and moderate turbid water (located at a distance greater than $25 \mathrm{~km}$ from the Southwest Pass) (Figure 3(g) and Figure 3(h)). At $561 \mathrm{~nm}$ and $655 \mathrm{~nm}$, nonlinearity was observed for values larger than $0.025 \mathrm{sr}^{-1}$ and $0.028 \mathrm{sr}^{-1}$, respectively.

The observed non-linearity with increasing SPM concentration emphasized that the NIR atmospheric correction was more likely to overestimate the aerosol reflectance and underestimate of water remote sensing reflectance in visible bands and SPM concentrations.

A good agreement was found between the corrected Rrs signals using NIR and 


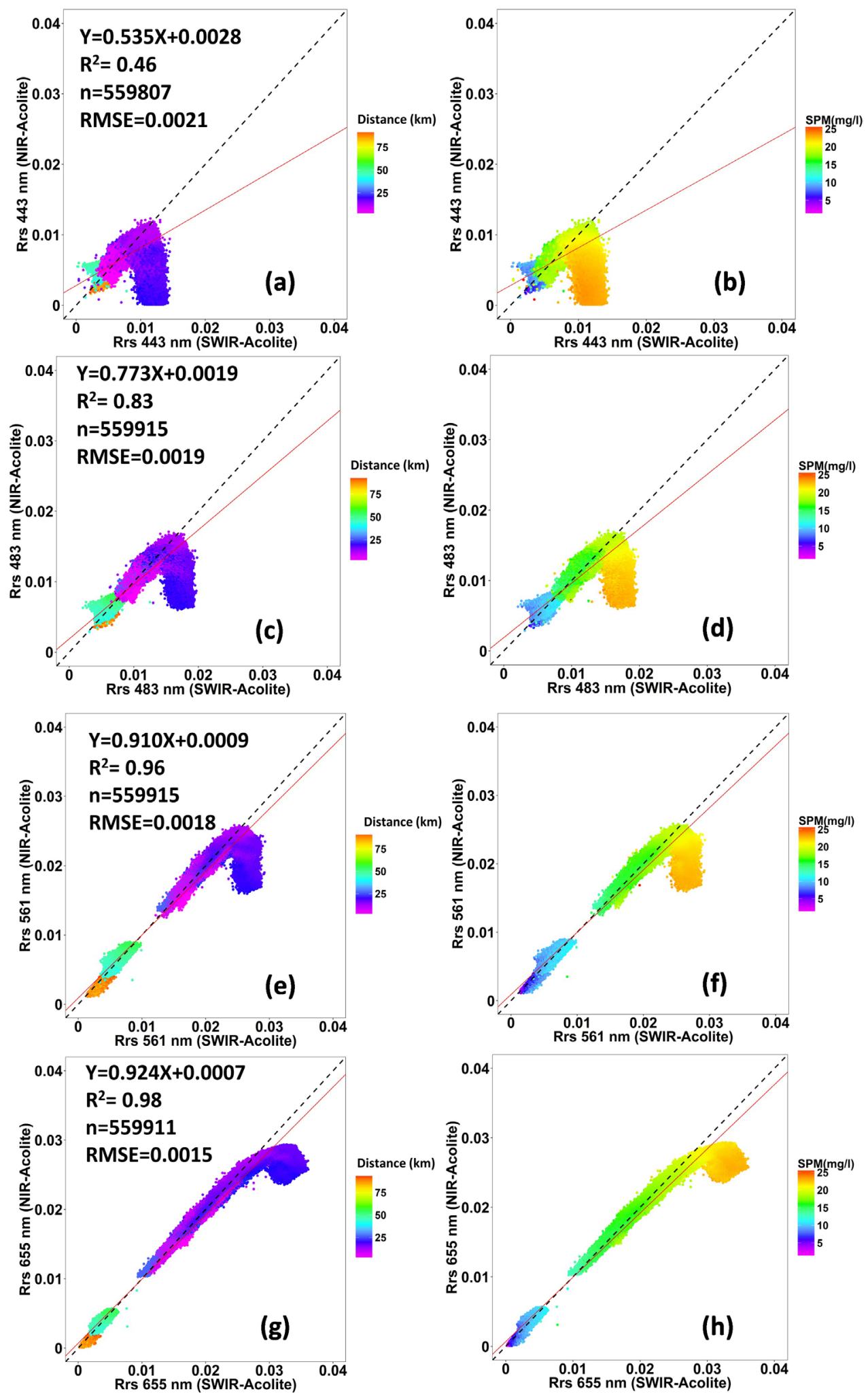

Figure 3. Scatter plots showing (a) through (h) the comparison of Landsat-8 OLI remote sensing reflectance (Rrs) at $443 \mathrm{~nm}, 483$ $\mathrm{nm}, 561 \mathrm{~nm}$, and $655 \mathrm{~nm}$ derived from the Landsat-8 OLI image on 23 April 2016 over the Mississippi River plume using NIR (y-axis) and SWIR (x-axis) atmospheric correction algorithms for low to high turbidity waters. Colors indicate the distance (km) from the Mississippi River, Southwest Pass (28 $\left.54^{\prime} 18^{\prime \prime} \mathrm{N} 89^{\circ} 25^{\prime} 42^{\prime \prime} \mathrm{W}\right)$ (left panel) and SPM concentrations (mg. ${ }^{-1}$ ) (right panel). The black dashed line is $1: 1$ and the regression line is drawn in red. 
Table 4. Statistics for estimated Landsat- 8 OLI Rrs $\left(\mathrm{sr}^{-1}\right)$ products processed by NIR and SWIR atmospheric correction algorithms in box 1,2,3, and all data points.

\begin{tabular}{|c|c|c|c|c|c|c|}
\hline Band & Box & BIAS (\%) & RMSE & SI & WI & $\mathrm{R}^{2}$ \\
\hline \multirow{4}{*}{$443 \mathrm{~nm}$} & 1 & 0.133 & 0.0025 & 0.27 & 0.39 & 0.008 \\
\hline & 2 & -0.030 & 0.0007 & 0.13 & 0.61 & 0.18 \\
\hline & 3 & 0.039 & 0.0005 & 0.10 & 0.72 & 0.47 \\
\hline & All & 0.087 & 0.0021 & 0.28 & 0.79 & 0.46 \\
\hline \multirow{4}{*}{$483 \mathrm{~nm}$} & 1 & 0.121 & 0.0023 & 0.15 & 0.52 & 0.05 \\
\hline & 2 & -0.024 & 0.0006 & 0.09 & 0.78 & 0.38 \\
\hline & 3 & 0.033 & 0.0004 & 0.07 & 0.68 & 0.43 \\
\hline & All & 0.080 & 0.0019 & 0.16 & 0.93 & 0.83 \\
\hline \multirow{4}{*}{$561 \mathrm{~nm}$} & 1 & 0.100 & 0.0021 & 0.08 & 0.79 & 0.46 \\
\hline & 2 & -0.017 & 0.0005 & 0.07 & 0.93 & 0.76 \\
\hline & 3 & 0.027 & 0.0004 & 0.09 & 0.89 & 0.78 \\
\hline & All & 0.070 & 0.0018 & 0.09 & 0.99 & 0.96 \\
\hline \multirow{4}{*}{$655 \mathrm{~nm}$} & 1 & 0.092 & 0.0019 & 0.07 & 0.93 & 0.76 \\
\hline & 2 & -0.010 & 0.0003 & 0.10 & 0.95 & 0.92 \\
\hline & 3 & 0.019 & 0.0003 & 0.19 & 0.82 & 0.93 \\
\hline & All & 0.061 & 0.0015 & 0.08 & 0.99 & 0.98 \\
\hline
\end{tabular}

SWIR atmospheric correction algorithms for bands $561 \mathrm{~nm}$ and $655 \mathrm{~nm}$ in low to moderate turbid waters (box 2 and box 3 (Figure 4)).

The NIR and SWIR atmospheric correction algorithms showed consistent results at $561 \mathrm{~nm}\left(\right.$ slope $\left.=1.04 ; \mathrm{R}^{2}=0.91\right)$ and $655 \mathrm{~nm}\left(\right.$ slope $\left.=1.02 ; \mathrm{R}^{2}=0.90\right)$ (Table 5) in low and moderate turbid water (box 2 and 3). The Rrs $\left(\mathrm{sr}^{-1}\right)$ products at $443 \mathrm{~nm}, 481 \mathrm{~nm}, 561 \mathrm{~nm}$, and $651 \mathrm{~nm}$ from ACOLITE NIR and SWIR atmospheric correction were also compared visually (Figure 5). The left panel presents corrected Rrs products using SWIR approach, and the right panel shows the corrected Rrs product using the NIR approach.

Figure 5 enhances our understanding of the performance of each approach and delivers the knowledge of which approach tends to overestimate and underestimate the remote sensing products.

As expected, the NIR correction tended to underestimate Rrs products due to overestimation of the aerosols reflectance. Generally, the highest Rrs values were found in the vicinity of the Mississippi River passes and in shallow coastal waters where significantly influenced by the Mississippi River plume and wave activities. Figure 5 shows that the SWIR approach (right) tended to estimate the higher value of Rrs than NIR approach (left).

\subsubsection{Evaluation of Retrieval SPM from Landsat-8 OLI}

Figure 6(a) and Figure 6(b) presents SPM concentration maps generated from SWIR- and NIR-corrected Rrs products. The results suggested that the Rrs 

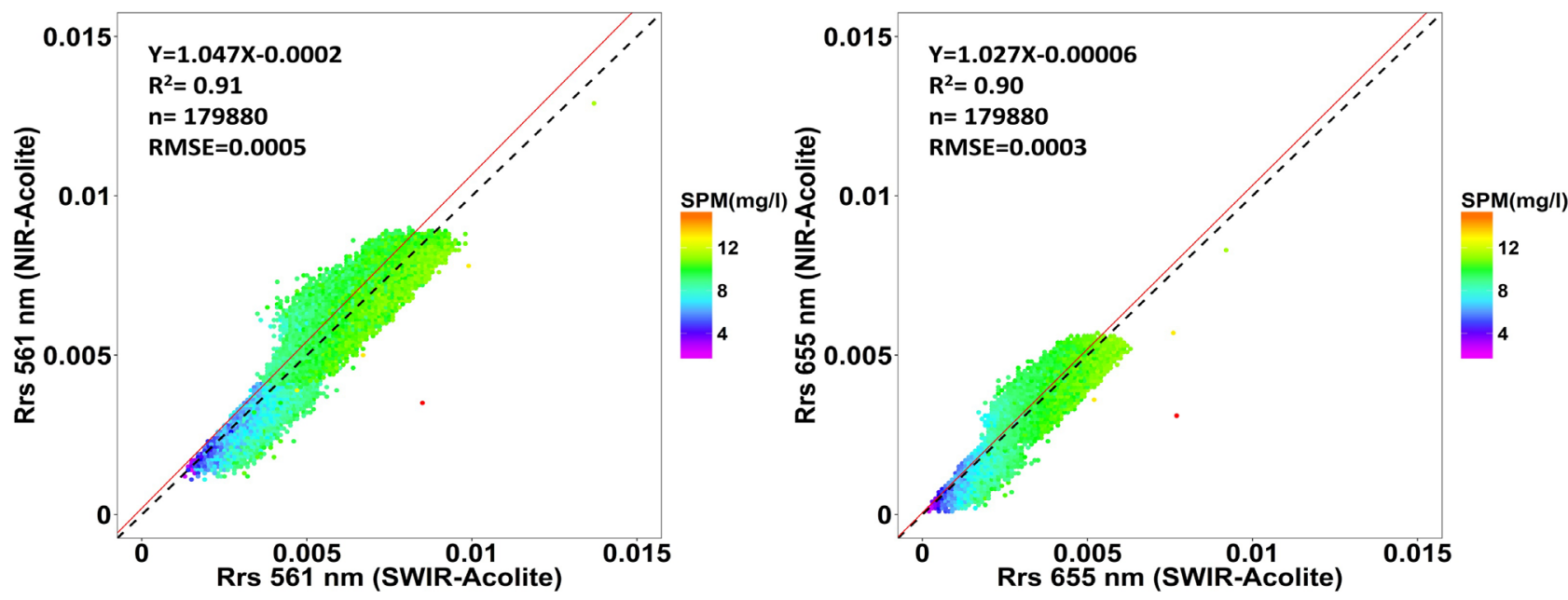

Figure 4. Scatter plots presenting the comparison of Landsat-8 OLI Rrs at (a) $561 \mathrm{~nm}$ and (b) $655 \mathrm{~nm}$ derived from the Landsat-8 OLI image on 23 April 2016 over the Mississippi River plume using NIR (y-axis) and SWIR (x-axis) atmospheric correction algorithms for low and moderate turbid water. The black dashed line is 1:1 and the regression line is drawn in red.

Table 5. Statistics for estimated Landsat-8 OLI Rrs $\left(\mathrm{sr}^{-1}\right)$ products at $561 \mathrm{~nm}$ and $655 \mathrm{~nm}$ processed by NIR and SWIR atmospheric correction algorithms in box 2 and 3 .

\begin{tabular}{cccccc}
\hline Product & BIAS (\%) & RMSE & SI & Willmott Index & $\mathrm{R}^{2}$ \\
\hline Rrs 561 $(\mathrm{nm})$ & -0.0052 & 0.0005 & 0.090 & 0.98 & 0.91 \\
Rrs 655 $(\mathrm{nm})$ & -0.0018 & 0.0003 & 0.123 & 0.97 & 0.90 \\
\hline
\end{tabular}

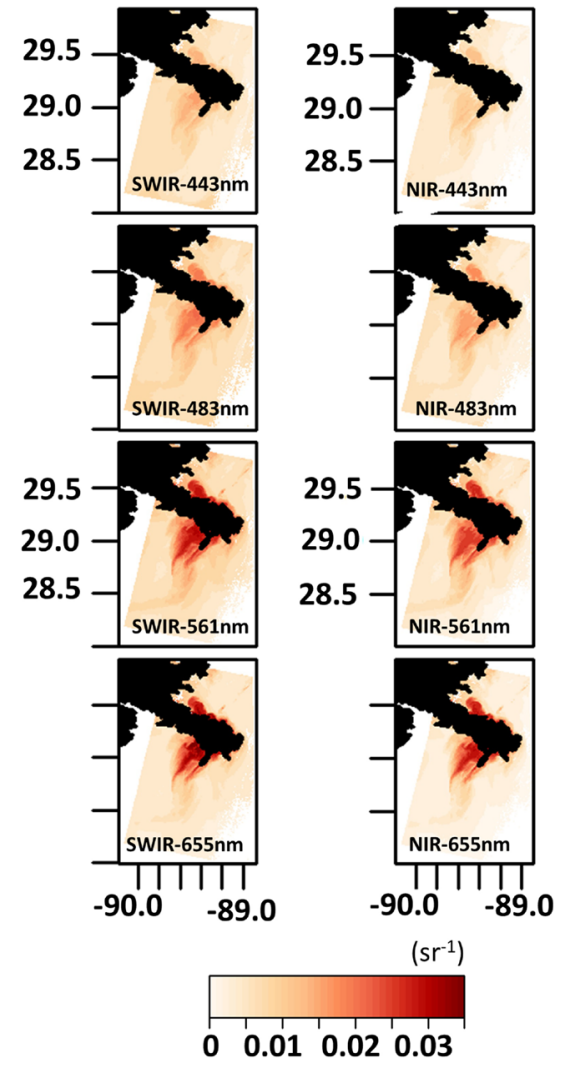

Figure 5. Comparison between corrected Landsat-8 OLI Rrs at 443, 483, 561 and $655 \mathrm{~nm}$ using ACOLITE SWIR (left panel) and NIR (right panel) atmospheric correction algorithm. 
products corrected by SWIR atmospheric correction algorithm resulted in higher SPM values compared to the SPM values obtained from Rrs products corrected by NIR method.

To validate the SWIR and NIR atmospheric correction approaches and SPM retrieval algorithm using Landsat-8 OLI data, the in situ-measured SPM obtained on 30 July 2014 [50] were compared with Landsat-8 OLI-retrieved SPM concentration (Table 6). Only SPM data pairs with a time difference of $\pm 3 \mathrm{hr}$ between in situ and Landsat-8 OLI were used.

The retrieved SPM concentrations using SWIR-corrected Rrs products (at 561 $\mathrm{nm}$ and $655 \mathrm{~nm}$ ) agreed with in situ-measured SPM with an average percentage difference of $10.18 \%$.
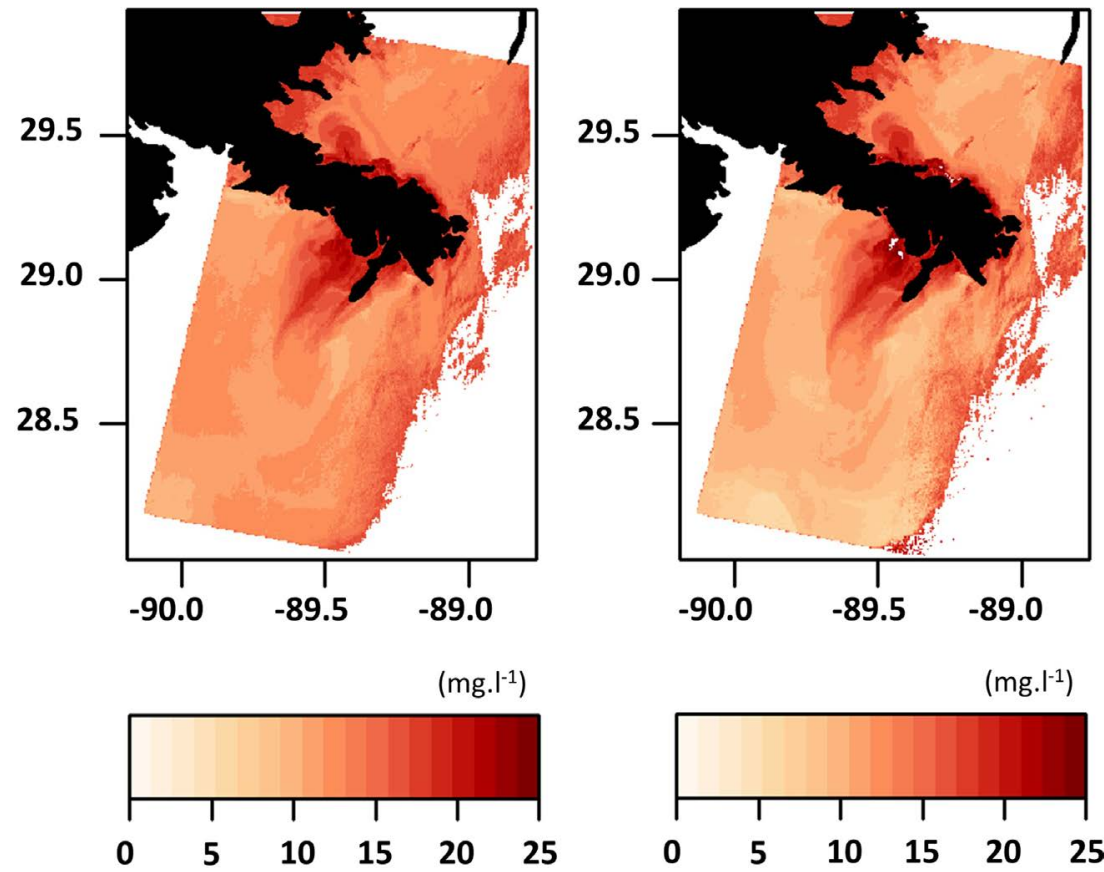

Figure 6. Comparison between retrieved SPM concentration (mg. $\mathrm{l}^{-1}$ ) (a) using Landsat-8 OLI SWIR-corrected Rrs (561 nm and $655 \mathrm{~nm}$ ), and (b) using Landsat-8 OLI NIR-corrected Rrs (561 nm and $655 \mathrm{~nm})$.

Table 6. In situ and OLI-retrieved SPM concentration (mg. $\left.1^{-1}\right)$ using SWIR and NIR corrected Rrs products on 30 July 2014. The computed percentage difference between in situ and OLI-retrieved SPM using SWIR and NIR atmospheric correction methods.

\begin{tabular}{ccccc}
\hline $\begin{array}{c}\text { in situ SPM } \\
\left(\mathrm{mg} \cdot \mathrm{l}^{-1}\right)\end{array}$ & $\begin{array}{c}\text { OLI SPM }\left(\mathrm{mg} \cdot{ }^{-1}\right) \\
(\text { SWIR method) }\end{array}$ & $\begin{array}{c}\text { OLI SPM } \\
\left(\mathrm{mg} \cdot \mathrm{l}^{-1}\right) \\
(\text { NIR method) }\end{array}$ & $\begin{array}{c}\text { Percent Difference } \\
\text { Between in situ \& OLI } \\
\text { SPM (SWIR method) }\end{array}$ & $\begin{array}{c}\text { Percent Difference } \\
\text { Between in situ \& OLI } \\
\text { SPM (NIR method) }\end{array}$ \\
\hline 15.0 & 14.10 & 12.62 & 6.12 & 17.2 \\
5.0 & 5.47 & 5.97 & 8.97 & 17.68 \\
16.8 & 13.62 & 12.41 & 20.90 & 30.05 \\
10.4 & 11.82 & 8.86 & 12.78 & 15.99 \\
9.2 & 9.40 & 8.20 & 2.15 & 10.40 \\
\hline
\end{tabular}


Whereas, an average percentage difference of $18.26 \%$ was observed between the retrieved SPM concentration using NIR-corrected Rrs products and in situ-measured SPM. Our results indicated that SWIR atmospheric correction algorithm was the most appropriated approach to measure SPM concentrations from Landsat-8 OLI in our study area. The observed discrepancies between Landsat-8 OLI-derived and in situ-measured SPM were likely due to the error associated with field measurements, uncertainties related to the SPM retrieval algorithms and atmospheric correction algorithms, and the spatial differences between Landsat-8 OLI pixel location and the sampling locations.

\subsection{MODIS Aqua}

\subsubsection{Comparison of Atmospheric Correction Approaches}

The remote sensing reflectance products at $443,488,555$, and $678 \mathrm{~nm}$ from SeaDAS SWIR.NIR algorithm were compared against the SeaDAS MUMM results. Table 7 provides the computed $5^{\text {th }}$ and $95^{\text {th }}$ percentile, percentage difference (Equation (5)), the median ratio (SWIR.NIR to MUMM) and SIQR (Equation (3)) for Rrs products in each type of water.

$$
\frac{\mid \text { MUMM }- \text { SWIR.NIR } \mid}{\text { MUMM }+ \text { SWIR.NIR }}=100
$$

Table 7 suggests as the turbidity increased (i.e., influenced by sediment discharge from the Mississippi River), the percentage difference increased as well. The MODIS-Aqua SWIR.NIR- and MUMM-corrected remote sensing reflectance products were plotted against each other and color-coded based on SPM

Table 7. $5^{\text {th }}$ and $95^{\text {th }}$ percentile for MODIS-retrieved Rrs $\left(\mathrm{sr}^{-1}\right)$ processed by SWIR.NIR and MUMM atmospheric correction algorithms, the percentage difference, median SWIR.NIR to MUMM ratio, and SIQR in box 1, 2 and 3 on 13 September 2013.

\begin{tabular}{|c|c|c|c|c|c|c|c|}
\hline Band & Box & $\begin{array}{l}5^{\text {th }} \text { percentile } \\
\text { SWIR.NIR approach }\end{array}$ & $\begin{array}{l}95^{\text {th }} \text { percentile } \\
\text { SWIR.NIR approach }\end{array}$ & $\begin{array}{c}5^{\text {th }} \text { percentile } \\
\text { MUMM approach }\end{array}$ & $\begin{array}{c}95^{\text {th }} \text { percentile } \\
\text { MUMM approach }\end{array}$ & $\begin{array}{l}\text { Percentage } \\
\text { Difference }\end{array}$ & $\begin{array}{c}\text { Median } \\
\text { Ratio (SIQR) }\end{array}$ \\
\hline \multirow{3}{*}{$443 \mathrm{~nm}$} & 1 & 0.0008 & 0.0050 & 0.0031 & 0.0060 & 42.26 & $0.503( \pm 0.072)$ \\
\hline & 2 & 0.0016 & 0.0023 & 0.0034 & 0.0055 & 38.81 & $0.443( \pm 0.024)$ \\
\hline & 3 & 0.0013 & 0.0032 & 0.0027 & 0.0046 & 26.16 & $0.434( \pm 0.058)$ \\
\hline \multirow{3}{*}{$488 \mathrm{~nm}$} & 1 & 0.0014 & 0.0074 & 0.0042 & 0.0089 & 30.02 & $0.653( \pm 0.068)$ \\
\hline & 2 & 0.0025 & 0.0031 & 0.0040 & 0.0057 & 29.68 & $0.583( \pm 0.023)$ \\
\hline & 3 & 0.0023 & 0.0035 & 0.0033 & 0.0048 & 27.50 & $0.568( \pm 0.036)$ \\
\hline \multirow{2}{*}{$555 \mathrm{~nm}$} & 1 & 0.0049 & 0.0128 & 0.0062 & 0.0138 & 30.42 & $0.837( \pm 0.034)$ \\
\hline & 3 & 0.0015 & 0.0019 & 0.0023 & 0.0029 & 25.56 & $0.653( \pm 0.019)$ \\
\hline \multirow{3}{*}{$678 \mathrm{~nm}$} & 1 & 0.0025 & 0.0094 & 0.0031 & 0.0099 & 34.27 & $0.823( \pm 0.044)$ \\
\hline & 2 & 0.0034 & 0.0024 & 0.0037 & 0.0028 & 32.06 & $0.658( \pm 0.049)$ \\
\hline & 3 & 0.0002 & 0.0003 & 0.0007 & 0.0009 & 29.52 & $0.339( \pm 0.027)$ \\
\hline
\end{tabular}


concentrations in low to high turbidity waters (Figure 7).

The best agreement was observed between atmospherically corrected Rrs at $678 \mathrm{~nm}\left(\mathrm{R}^{2}=0.93\right.$, slope $\left.=0.98\right)$ followed by $\mathrm{Rrs}$ at $555 \mathrm{~nm}\left(\mathrm{R}^{2}=0.91\right.$, slope $=$ 0.99). The low $R^{2}$ was obtained for the shorter wavelengths at $488 \mathrm{~nm}$ and 443 $\mathrm{nm}(0.54$ and 0.27$)$. Figures 7 (a)-(d) shows that the estimated Rrs resided above 1:1, which implies that the MUMM algorithm tended to estimate the higher value of Rrs than SWIR.NIR. A comparison of atmospheric correction approaches for MODIS-Aqua indicates that SWIR.NIR algorithm estimated the lower value of Rrs than the MUMM algorithm.

Figure 8 presents the visual comparison of the corrected remote sensing reflectance products using SWIR.NIR (left panel) and MUMM (right panel) atmospheric correction algorithms from SeaDAS in the northern Gulf of Mexico on 13 September 2013. Table 8 presents the statistical parameters for MODIS-Aqua
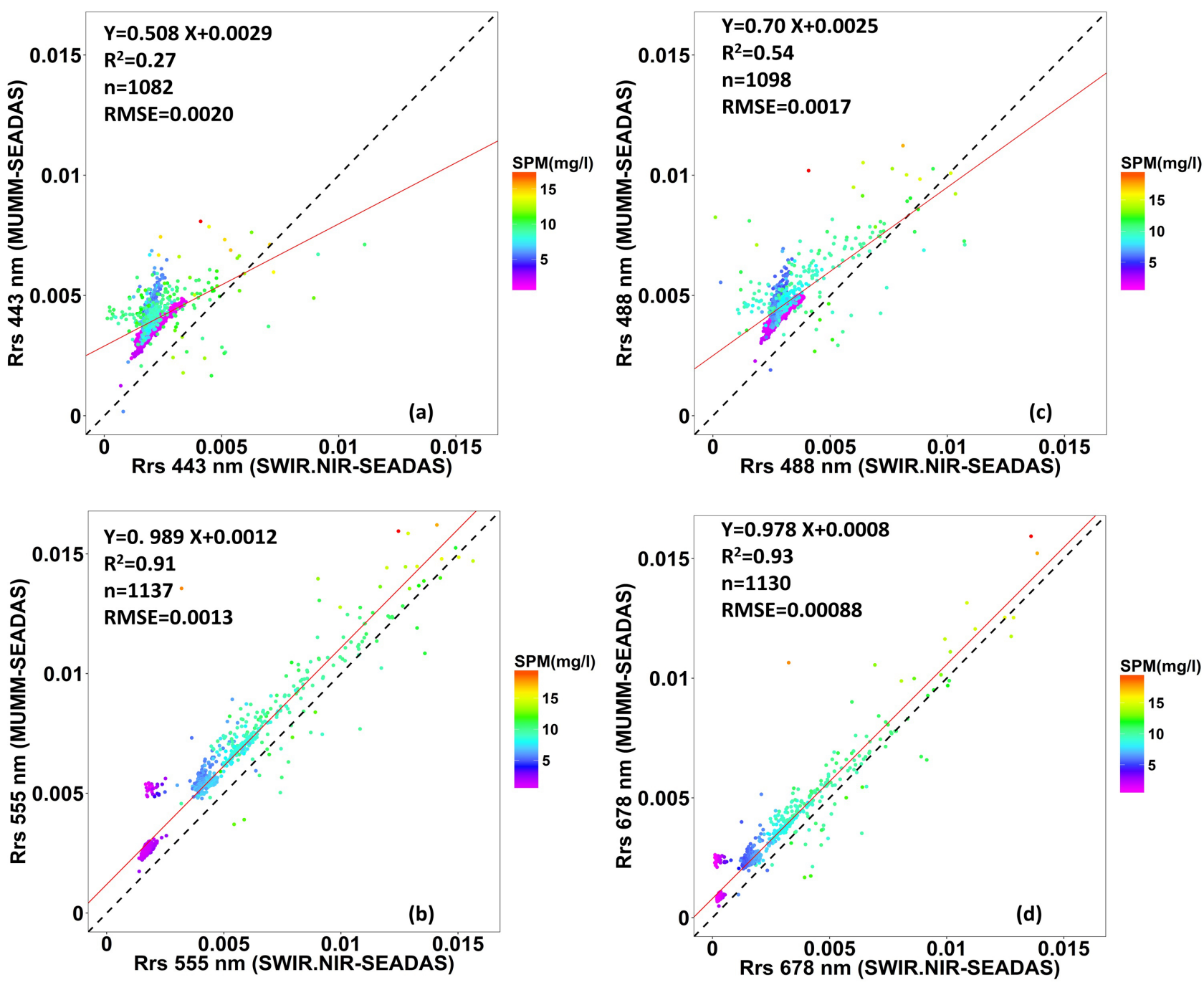

Figure 7. Scatter plots (a-d) present the comparison of the MODIS-Aqua atmospherically corrected remote sensing reflectance (Rrs) at 443, 488, 555, and $678 \mathrm{~nm}$ using SWIR.NIR (x-axis) and MUMM (y-axis) algorithms on 13 September 2013 image for low to high turbidity waters. The color bar indicates the SPM concentrations (mg.l-1). The black dashed line is 1:1 and the regression line is drawn in red. 


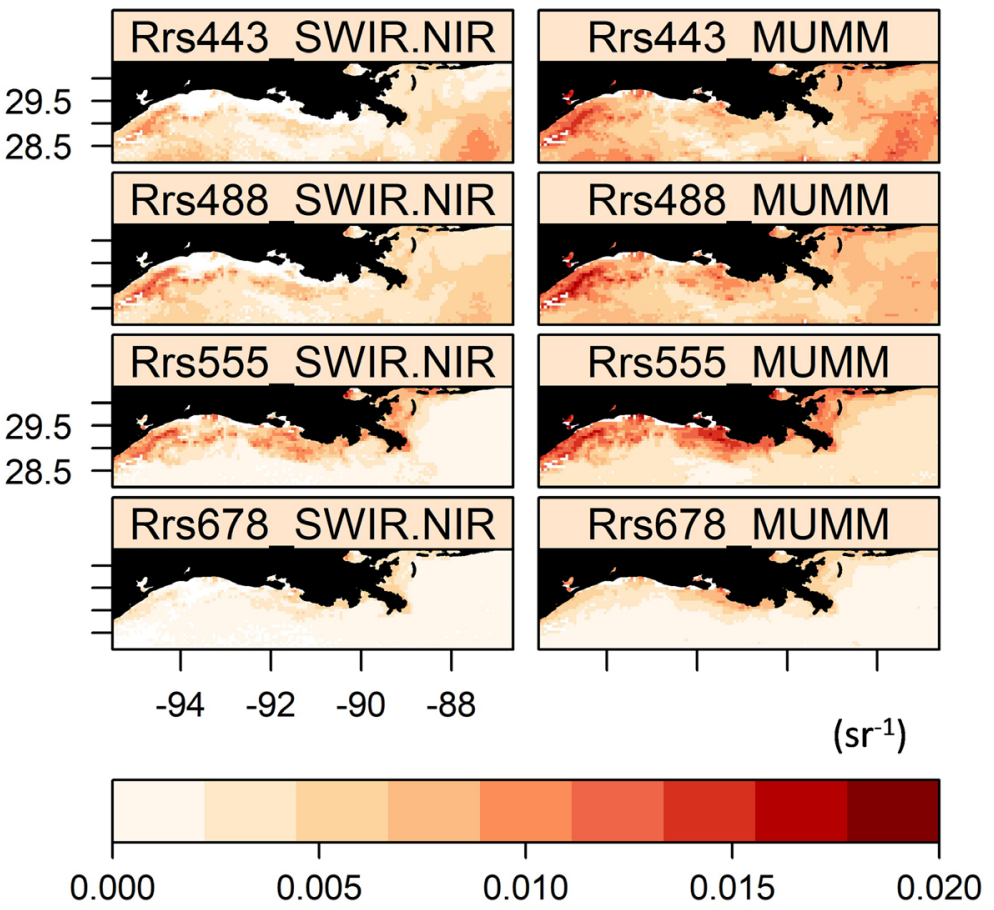

Figure 8. The atmospherically corrected Remote sensing reflectance $\left(\mathrm{Rrs}, \mathrm{sr}^{-1}\right)$ at $443 \mathrm{~nm}$, $488 \mathrm{~nm}, 555 \mathrm{~nm}$ and $678 \mathrm{~nm}$ using SWIR.NIR-SeaDAS (right panel), MUMM-SeaDAS (left panel) on 13 September 2013.

Table 8. Statistics for estimated MODIS Rrs $\left(\mathrm{sr}^{-1}\right)$ products processed by SWIR.NIR and MUMM atmospheric correction algorithms in box 1,2,3, and all data points.

\begin{tabular}{|c|c|c|c|c|c|c|}
\hline Band & Box & BIAS (\%) & RMSE & SI & WI & $\mathrm{R}^{2}$ \\
\hline \multirow{4}{*}{$443 \mathrm{~nm}$} & 1 & -0.161 & 0.0019 & 0.24 & 0.43 & 0.28 \\
\hline & 2 & -0.238 & 0.0024 & 0.10 & 0.26 & 0.52 \\
\hline & 3 & -0.150 & 0.0015 & 0.08 & 0.42 & 0.78 \\
\hline & All & 0.190 & 0.0020 & 0.20 & 0.42 & 0.27 \\
\hline \multirow{4}{*}{$488 \mathrm{~nm}$} & 1 & -0.190 & 0.0019 & 0.07 & 0.21 & 0.44 \\
\hline & 2 & -0.160 & 0.0018 & 0.17 & 0.70 & 0.64 \\
\hline & 3 & -0.120 & 0.0012 & 0.06 & 0.42 & 0.75 \\
\hline & All & 0.160 & 0.0017 & 0.16 & 0.58 & 0.54 \\
\hline \multirow{4}{*}{$555 \mathrm{~nm}$} & 1 & -0.089 & 0.0009 & 0.06 & 0.24 & 0.30 \\
\hline & 2 & -0.151 & 0.0016 & 0.09 & 0.35 & 0.48 \\
\hline & 3 & -0.120 & 0.0014 & 0.10 & 0.90 & 0.87 \\
\hline & All & 0.110 & 0.0013 & 0.41 & 0.92 & 0.92 \\
\hline \multirow{4}{*}{$678 \mathrm{~nm}$} & 1 & -0.055 & 0.0005 & 0.07 & 0.17 & 0.38 \\
\hline & 2 & -0.080 & 0.0009 & 0.14 & 0.47 & 0.41 \\
\hline & 3 & -0.072 & 0.0010 & 0.15 & 0.94 & 0.87 \\
\hline & All & 0.071 & 0.0008 & 0.21 & 0.95 & 0.93 \\
\hline
\end{tabular}


Rrs products corrected using SWIR.NIR and MUMM atmospheric correction algorithm. The results indicate that the agreement between the Rrs products processed by SWIR.NIR and MUMM decreased as the turbidity increased. For example, at $678 \mathrm{~nm}$ the $\mathrm{R}^{2}$ value decreased from 0.87 (in box 3; low turbid) to 0.38 (in box 1; high turbid) as the distance from the Mississippi River which supplies sediment decreased.

Figure 9 presents the MODIS-derived SPM concentration maps using corrected Rrs (555 nm and $678 \mathrm{~nm}$ ) by SWIR.NIR (Figure 6(a)) and MUMM (Figure 6(b)) approaches on 13 September 2013. In general, SPM concentration values from corrected Rrs by MUMM approach were higher than SPM concentration values retrieved from SWIR.NIR-corrected Rrs. Converse to the corrected Landsat-8 OLI Rrs products, the point cloud feature dipping below 1:1 (Figure 3) was not observed in Figure 7. The lower radiometric sensitivity of MODIS may explain why this feature was not observed for MODIS-Aqua. The MODIS data from September 2013 were collected when the Mississippi River exhibited a much lower discharge $\left(\sim 6698.4 \mathrm{~m}^{3} \cdot \mathrm{s}^{-1}\right.$ at Belle Chasse station) compared to the discharge of the Mississippi River at Belle Chasse during the Landsat-8 OLI overpass $\left(\sim 22,115 \mathrm{~m}^{3} \cdot \mathrm{s}^{-1}\right)$ in April 2016, which could lead to substantially more turbid waters, and thus brighter red reflectance. The maximum value of $\sim 0.0155 \mathrm{sr}^{-1}$ was observed in high turbidity at Rrs $(655 \mathrm{~nm})$ retrieved from MODIS (Figure 7(b)), whereas the maximum value of Landsat-8 OLI Rrs at $655 \mathrm{~nm}$ on 23 April 2016 was $0.035 \mathrm{sr}^{-1}$ (Figure 3(g)). In addition, the use of high-quality SWIR bands of Landsat-8 OLI leads to an accurate quantification

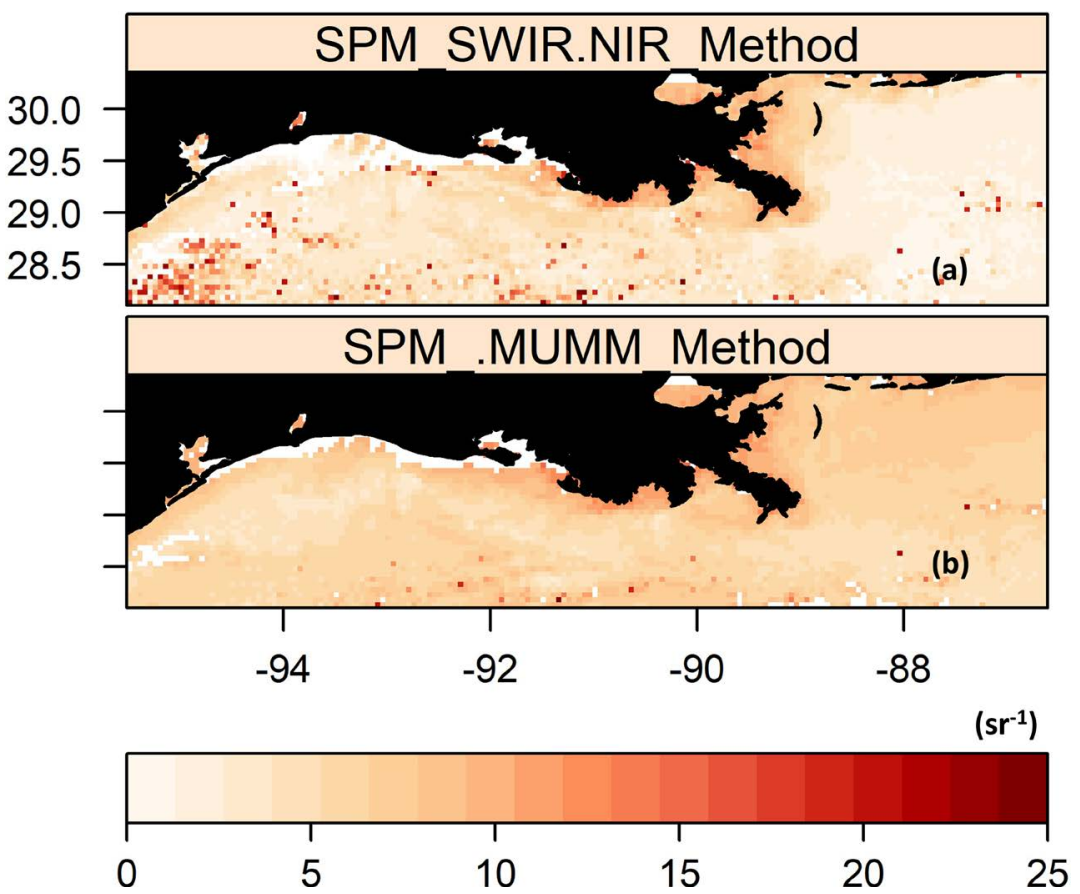

Figure 9. Comparison between MODIS-retrieved SPM concentration using corrected remote sensing reflectance products by (a) SWIR.NIR and (b) MUMM methods on 13 September 2013. 
of the aerosol contribution to the top of the atmosphere and Rrs products. Whereas, MODIS SWIR bands (1240 $\mathrm{nm}$ and $2130 \mathrm{~nm}$ ) are quite noisy due to the low SNR, which is considered as a shortcoming of the sensor in terms of atmospheric correction approach [57].

\subsubsection{Evaluation of Retrieved SPM from MODIS-Aqua}

Figure 10 shows the match-ups between MODIS-derived SPM concentration and in situ-measured SPM concentration. We observed a relatively high agreement (Figure 10(a)) between MODIS-derived SPM concentration processed with SWIR.NIR atmosphere correction algorithm $\left(R^{2}=0.79\right.$, bias $\left.=0.63\right)$, while retrieved SPM concentration processed with MUMM algorithm suggested a lower agreement (Figure $10(b))$ with field data $\left(R^{2}=0.76\right.$, bias $\left.=1.23\right)$, see Table 1 and Figure 2 for data points used in the comparison. Note that to perfume the match-up comparison, the time difference of $\pm 3 \mathrm{hr}$ between in situ-measured SPM and MODIS-Aqua overpasses was considered.

The performance of each atmospheric correction algorithms in retrieving SPM was assessed using BIAS, RMSE, SI, and $\mathrm{R}^{2}$ (Table 9). The comparison between in situ SPM and MODIS-derived SPM suggested that the SWIR.NIR atmosphere correction algorithm was the most appropriate algorithm in our study area (Figure 10 and Table 9). The observed disagreement between MODIS-derived and in situ-measured SPM was attributable to the low spatial resolution $(1 \mathrm{~km})$ of MODIS, low SNR values of MODIS-Aqua SWIR bands. In addition, errors
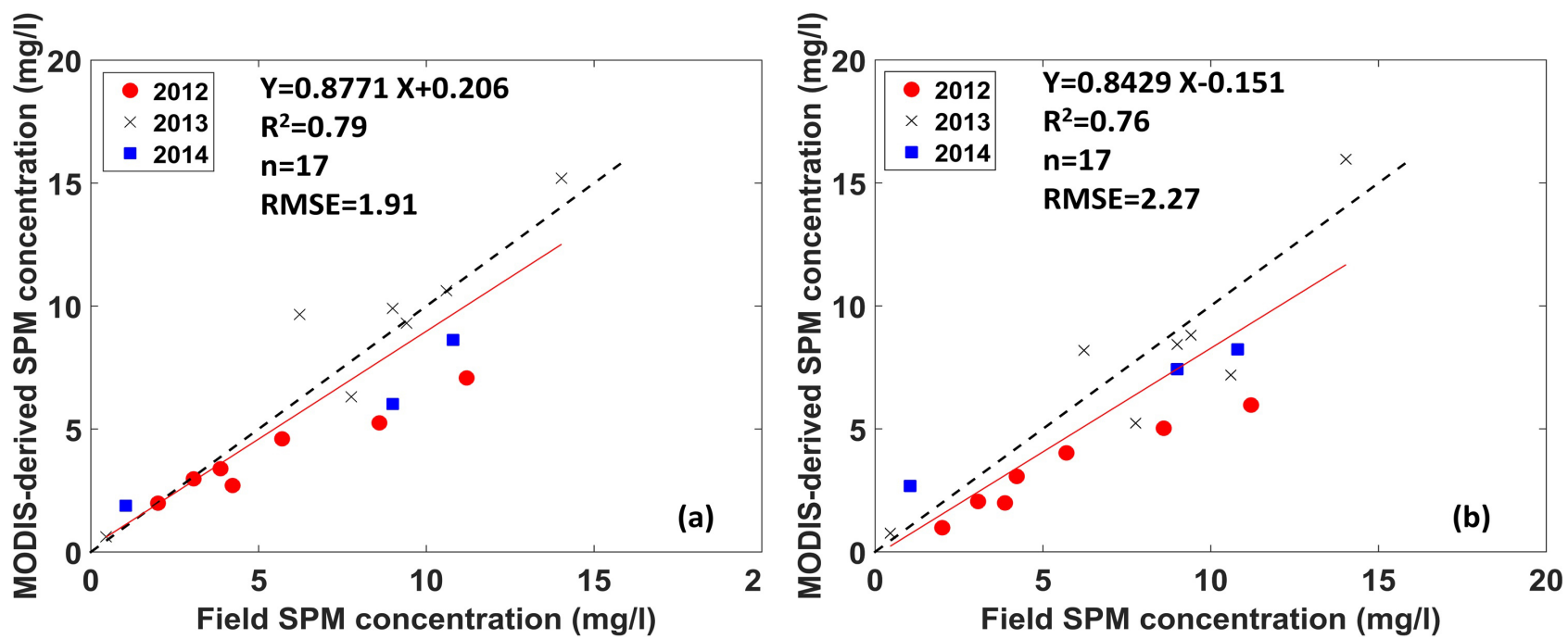

Figure 10. Comparison of in situ-measured SPM concentration (mg. $\mathrm{l}^{-1}$ ) with MODIS Aqua-retrieved SPM concentration processed using (a) SWIR.NIR and (b) MUMM.

Table 9. Statistics for SPM concentration obtained from MODIS-Aqua Rrs products corrected by SWIR.NIR and MUMM atmospheric correction methods.

\begin{tabular}{ccccc}
\hline Product & BIAS & RMSE & SI & $\mathrm{R}^{2}$ \\
\hline SPM from SWIR.NIR-corrected Rrs & 0.63 & 1.91 & 0.27 & 0.78 \\
SPM from MUMM-corrected Rrs & 1.23 & 2.27 & 1.23 & 0.76 \\
\hline
\end{tabular}


associated with the atmospheric correction processes and SPM retrieval algorithm would exacerbate the disagreement between satellite-derived and field SPM concentration.

\section{Summary and Conclusions}

To monitor SPM dynamics using satellite data in Louisiana coastal and shelf waters, appropriate atmospheric correction algorithms and robust SPM retrieval algorithms are required. The performance of the four atmospheric correction algorithms was evaluated: the SWIR and NIR atmospheric correction algorithms for Landsat-8 OLI and the MUMM along with the SWIR.NIR atmospheric correction algorithm for MODIS-Aqua. The results suggested that the NIR algorithm retrieved lower values of Rrs products from Landsat-8 OLI in high turbidity waters.

The SPM retrieval algorithm was applied to the corrected Rrs products from Landsat-8 OLI and MODIS-Aqua to estimate SPM concentrations. The Landsat-8 OLI Rrs products corrected atmospherically by the SWIR algorithm, retrieved more accurate SPM concentrations in our study area. In addition, a good agreement was found between MODIS-derived SPM processed with SWIR.NIR algorithm and field data. However, more in situ SPM data are needed to stress the robustness of these algorithms in our study area. In addition, it is strongly suggested to evaluate the performance of the revised Rrs (NIR) model [58] in the northern Gulf of Mexico. This model has been implemented by the NASA Ocean Biology Processing Group (OBPG) in the operational processing of satellite ocean color sensor data.

The observed imperfections between satellite-derived and in situ-measured SPM concentrations could be due to several factors related to the satellite's characteristics and errors and assumptions in the SPM retrieval algorithm used in this study [59]. The results underline the necessity of in situ measurements of Rrs products and SPM data to validate SPM retrieval algorithms. Furthermore, our findings highlight that multi-conditional SPM retrieval algorithms based on turbidity level must be considered in our study region. The use of multi-conditional SPM retrieval algorithms switching from red-NIR algorithms to visible band ratio algorithms would improve the accuracy of retrieved SPM. Hence, hyperspectral reflectance measurements must be carried out over low- to high turbidity waters.

SPM concentrations maps derived from satellites can be used to validate sediment transport and ecological models. The results of the present study are being used in an ongoing study for the numerical simulation of sediment transport in Gulf of Mexico, over the Louisiana shelf.

\section{References}

[1] Joshi, I.D., D’Sa, E.J., Osburn, C.L., Bianchi, T.S., Ko, D.S., Oviedo-Vargas, D., et al. (2017) Assessing Chromophoric Dissolved Organic Matter (CDOM) Distribution, Stocks, and Fluxes in Apalachicola Bay Using Combined Field, VIIRS Ocean Color, and Model Observations. Remote Sensing of Environment, 191, 359-372. 
https://doi.org/10.1016/j.rse.2017.01.039

[2] Ma, G., Han, Y., Niroomandi, A., Lou, S. and Liu, S. (2015) Numerical Study of Sediment Transport on a Tidal Flat with a Patch of Vegetation. Ocean Dynamics, 65, 203-222. https://doi.org/10.1007/s10236-014-0804-8

[3] Niroomandi, A., Ma, G., Su, S.-F., Gu, F. and Qi, D. (2017) Sediment Flux and Sediment-Induced Stratification in the Changjiang Estuary. Journal of Marine Science and Technology, 1-15.

[4] Kirk, J.T. (1994) Light and Photosynthesis in Aquatic Ecosystems. 3rd Edition, Cambridge University Press, Cambridge.

[5] Allahdadi, M.N, Felix, J., Stone, W.G. and D’Sa., E.J. (2011) The Fate of Sediment Plumes Discharged from the Mississippi and Atchafalaya Rivers: An Integrated Observation and Modeling Study for the Louisiana Shelf, USA. Proceedings of the Coastal Sediments, Miami, 2-6 May 2011, 2212-2225.

https://doi.org/10.1142/9789814355537_0166

[6] Blaas, M., El Serafy, G.Y.H., van Kessel, T., de Boer, G.J., Eleveld, M.A. and Van der Woerd, H.J. (2007) Data Model Integration of SPM Transport in the Dutch Coastal Zone. Proceedings of the Joint 2007 EUMETSATI AMS Conference, Darmstadt.

[7] D'Sa, E.J., Roberts, H. and Allahdadi, M.N. (2011) Suspended Particulate Matter Dynamics along the Louisiana-Texas Coast from Satellite Observations. Proceedings of the Coastal Sediments, Miami, 2-6 May 2011, 2390-2402. https://doi.org/10.1142/9789814355537_0179

[8] Miller, R.L. and McKee, B.A. (2004) Using MODIS Terra $250 \mathrm{~m}$ Imagery to Map Concentrations of Total Suspended Matter in Coastal Waters. Remote Sensing of Environment, 93, 259-266. https://doi.org/10.1016/j.rse.2004.07.012

[9] Vanhellemont, Q. and Ruddick, K. (2014) Turbid Wakes Associated with Offshore Wind Turbines Observed with Landsat 8. Remote Sensing of Environment, 145, 105-115. https://doi.org/10.1016/j.rse.2014.01.009

[10] Ody, A., Doxaran, D., Vanhellemont, Q., Nechad, B., Novoa, S., Many, G., et al. (2016) Potential of High Spatial and Temporal Ocean Color Satellite Data to Study the Dynamics of Suspended Particles in a Micro-Tidal River Plume. Remote Sensing, 8, 245. https://doi.org/10.3390/rs8030245

[11] Novoa, S., Doxaran, D., Ody, A., Vanhellemont, Q., Lafon, V., Lubac, B., et al. (2017) Atmospheric Corrections and Multi-Conditional Algorithm for Multi-Sensor Remote Sensing of Suspended Particulate Matter in Low-to-High Turbidity Levels Coastal Waters. Remote Sensing, 9, 61. https://doi.org/10.3390/rs9010061

[12] Vanhellemont, Q. and Ruddick, K. (2015) Advantages of High Quality SWIR Bands for Ocean Colour Processing: Examples from Landsat-8. Remote Sensing of Environment, 161, 89-106. https://doi.org/10.1016/j.rse.2015.02.007

[13] Hestir, E.L., Brando, V.E., Bresciani, M., Giardino, C., Matta, E., Villa, P., et al. (2015) Measuring Freshwater Aquatic Ecosystems: The Need for a Hyperspectral Global Mapping Satellite Mission. Remote Sensing of Environment, 167, 181-195. https://doi.org/10.1016/j.rse.2015.05.023

[14] Allahdadi, M.N., Jose, F., D’Sa, E.J. and Ko, D.S. (2017) Effect of Wind, River Discharge, and Outer-Shelf Phenomena on Circulation Dynamics of the Atchafalaya Bay and Shelf. Ocean Engineering, 129, 567-580. https://doi.org/10.1016/j.oceaneng.2016.10.035

[15] Allahdadi, M.N. and Li, C. (2017) Numerical Simulation of Louisiana Shelf Circulation under Hurricane Katrina. Journal of Coastal Research, 34, 67-80.

[16] Feng, Z. (2009) Hydrodynamic Response to Cold Fronts along the Louisiana Coast. 
MSc Theses, Louisiana State University, Baton Rouge.

[17] Georgiou, I.Y., FitzGerald, D.M. and Stone, G.W. (2005) The Impact of Physical Processes along the Louisiana Coast. Journal of Coastal Research, 44, 72-89.

[18] Roberts, H.H., Huh, O.K., Hsu, S.A., Rouse, L.J. and Rickman, D. (1987) Impact of Coldfront Passages on Geomorphic Evolution and Sediment Dynamics of the Complex Louisiana Coast. Proceedings of a Specialty Conference, New Orleans.

[19] Li, C., Roberts, H., Stone, G.W., Weeks, E. and Luo, Y. (2011) Wind Surge and Saltwater Intrusion in Atchafalaya Bay during Onshore Winds Prior to Cold Front Passage. Hydrobiologia, 658, 27-39. https://doi.org/10.1007/s10750-010-0467-5

[20] Walker, N.D. and Hammack, A.B. (2000) Impacts of Winter Storms on Circulation and Sediment Transport: Atchafalaya-Vermilion Bay Region, Louisiana, U.S.A. Journal of Coastal Research, 16, 996-1010.

[21] Chen, J., D’Sa, E., Cui, T. and Zhang, X. (2013) A Semi-Analytical Total Suspended Sediment Retrieval Model in Turbid Coastal Waters: A Case Study in Changiiang River Estuary. Optics Express, 21, 13018-13031.

https://doi.org/10.1364/OE.21.013018

[22] Dogliotti, A.I., Ruddick, K.G., Nechad, B., Doxaran, D. and Knaeps, E. (2015) A Single Algorithm to Retrieve Turbidity from Remotely-Sensed Data in All Coastal and Estuarine Waters. Remote Sensing of Environment, 156, 157-168. https://doi.org/10.1016/j.rse.2014.09.020

[23] D’Sa, E.J., Miller, R.L. and McKee, B.A. (2007) Suspended Particulate Matter Dynamics in Coastal Waters from Ocean Color: Application to the Northern Gulf of Mexico. Geophysical Research Letters, 34, L23611.

[24] Nechad, B., Ruddick, K.G. and Park, Y. (2010) Calibration and Validation of a Generic Multisensor Algorithm for Mapping of Total Suspended Matter in Turbid Waters. Remote Sensing of Environment, 114, 854-866. https://doi.org/10.1016/j.rse.2009.11.022

[25] Nechad, B., Alvera-Azcaràte, A., Ruddick, K. and Greenwood, N. (2011) Reconstruction of MODIS Total Suspended Matter Time Series Maps by DINEOF and Validation with Autonomous Platform Data. Ocean Dynamics, 61, 1205-1214. https://doi.org/10.1007/s10236-011-0425-4

[26] Van der Woerd, H. and Pasterkamp, R. (2004) Mapping of the North Sea Turbid Coastal Waters Using SeaWiFS Data. Canadian Journal of Remote Sensing, 30, 44-53. https://doi.org/10.5589/m03-051

[27] Doxaran, D., Froidefond, J.-M., Lavender, S. and Castaing, P. (2002) Spectral Signature of Highly Turbid Waters: Application with SPOT Data to Quantify Suspended Particulate Matter Concentrations. Remote Sensing of Environment, 81, 149-161. https://doi.org/10.1016/S0034-4257(01)00341-8

[28] Shen, F., Verhoef, W., Zhou, Y., Salama, M.S. and Liu, X. (2010) Satellite Estimates of Wide-Range Suspended Sediment Concentrations in Changjiang (Yangtze) Estuary Using MERIS Data. Estuaries and Coasts, 33, 1420-1429. https://doi.org/10.1007/s12237-010-9313-2

[29] Doxaran, D., Froidefond, J.-M., Castaing, P. and Babin, M. (2009) Dynamics of the Turbidity Maximum Zone in a Macrotidal Estuary (the Gironde, France): Observations from Field and MODIS Satellite Data. Estuarine, Coastal and Shelf Science, 81, 321-332. https://doi.org/10.1016/j.ecss.2008.11.013

[30] Gordon, H.R. (1997) Atmospheric Correction of Ocean Color Imagery in the Earth Observing System Era. Journal of Geophysical Research: Atmospheres, 102, 17081 17106. https://doi.org/10.1029/96JD02443 
[31] Gordon, H.R. and Wang, M. (1994) Retrieval of Water-Leaving Radiance and Aerosol Optical Thickness over the Oceans with SeaWiFS: A Preliminary Algorithm. Applied Optics, 33, 443-452. https://doi.org/10.1364/AO.33.000443

[32] Ruddick, K.G., Ovidio, F. and Rijkeboer, M. (2000) Atmospheric Correction of SeaWiFS Imagery for Turbid Coastal and Inland Waters. Applied Optics, 39, 897-912. https://doi.org/10.1364/AO.39.000897

[33] Dogliotti, A., Ruddick, K., Nechad, B. and Lasta, C. (2011) Improving Water Reflectance Retrieval from MODIS Imagery in the Highly Turbid Waters of La Plata River. Proceedings of the 6 th International Conference Current Problems in Optics of Natural Waters, St. Petersburg, 6-9 September 2011, 1-8.

[34] Wang, M. and Shi, W. (2007) The NIR-SWIR Combined Atmospheric Correction Approach for MODIS Ocean Color Data Processing. Optics Express, 15, 1572215733. https://doi.org/10.1364/OE.15.015722

[35] Vanhellemont, Q., Neukermans, G. and Ruddick, K. (2014) Synergy between Polar-Orbiting and Geostationary Sensors: Remote Sensing of the Ocean at High Spatial and High Temporal Resolution. Remote Sensing of Environment, 146, 49-62. https://doi.org/10.1016/j.rse.2013.03.035

[36] Wang, M. (2007) Remote Sensing of the Ocean Contributions from Ultraviolet to Near-Infrared Using the Shortwave Infrared Bands: Simulations. Applied Optics, 46, 1535-1547. https://doi.org/10.1364/AO.46.001535

[37] Wang, M., Son, S. and Shi, W. (2009) Evaluation of MODIS SWIR and NIR-SWIR Atmospheric Correction Algorithms Using SeaBASS Data. Remote Sensing of Environment, 113, 635-644. https://doi.org/10.1016/j.rse.2008.11.005

[38] Milliman, J.D. and Farnsworth, K.L. (2012) River Discharge to the Coastal Ocean: A Global Synthesis. Cambridge University Press, Cambridge.

[39] Twilley, R.R., Bentley, S.J., Chen, Q., Edmonds, D.A., Hagen, S.C., Lam, N.S.-N., et al. (2016) Co-Evolution of Wetland Landscapes, Flooding, and Human Settlement in the Mississippi River Delta Plain. Sustainability Science, 11, 711-731. https://doi.org/10.1007/s11625-016-0374-4

[40] Hu, C., Nelson, J.R., Johns, E., Chen, Z., Weisberg, R.H. and Müller-Karger, F.E. (2005) Mississippi River Water in the Florida Straits and in the Gulf Stream off Georgia in Summer 2004. Geophysical Research Letters, 32, L14606. https://doi.org/10.1029/2005GL022942

[41] Meade, R.H. and Parker, R.S. (1984) Sediment in Rivers of the United States National Water Summary, 1984 Water Supply Paper. US Geological Survey 1985, Reston VA, 40-60.

[42] Dinnel, S.P. and Wiseman, W.J. (1986) Fresh Water on the Louisiana and Texas Shelf. Continental Shelf Research, 6, 765-784.

https://doi.org/10.1016/0278-4343(86)90036-1

[43] Lohrenz, S.E., Fahnenstiel, G.L., Redalje, D.G., Lang, G.A., Dagg, M.J., Whitledge, T.E., et al. (1999) Nutrients, Irradiance, and Mixing as Factors Regulating Primary Production in Coastal Waters Impacted by the Mississippi River Plume. Continental Shelf Research, 19, 1113-1141. https://doi.org/10.1016/S0278-4343(99)00012-6

[44] Rabalais, N.N., Turner, R.E., JustiĆ, D., Dortch, Q., Wiseman, W.J. and Gupta, B.K.S. (1996) Nutrient Changes in the Mississippi River and System Responses on the Adjacent Continental Shelf. Estuaries, 19, 386-407. https://doi.org/10.2307/1352458

[45] Tehrani, N.C., D’Sa, E.J., Osburn, C.L., Bianchi, T.S. and Schaeffer, B.A. (2013) Chromophoric Dissolved Organic Matter and Dissolved Organic Carbon from Sea-Viewing Wide Field-of-View Sensor (SeaWiFS), Moderate Resolution Imaging 
Spectroradiometer (MODIS) and MERIS Sensors: Case Study for the Northern Gulf of Mexico. Remote Sensing, 5, 1439-1464. https://doi.org/10.3390/rs5031439

[46] Cochrane, J.D. and Kelly, F.J. (1986) Low-Frequency Circulation on the TexasLouisiana Continental Shelf. Journal of Geophysical Research: Oceans, 91, 1064510659. https://doi.org/10.1029/JC091iC09p10645

[47] Chaichitehrani, N., D’Sa, E.J., Ko, D.S., Walker, N.D., Osburn, C.L. and Chen, R.F. (2013) Colored Dissolved Organic Matter Dynamics in the Northern Gulf of Mexico from Ocean Color and Numerical Model Results. Journal of Coastal Research, 30, $800-814$.

[48] Hitchcock, G.L., Wiseman, W.J., Boicourt, W.C., Mariano, A.J., Walker, N., Nelsen, T.A., et al. (1997) Property Fields in an Effluent Plume of the Mississippi River. Journal of Marine Systems, 12, 109-126. https://doi.org/10.1016/S0924-7963(96)00092-9

[49] Salisbury, J.E., Campbell, J.W., Linder, E., David Meeker, L., Müller-Karger, F.E. and Vörösmarty, C.J. (2004) On the Seasonal Correlation of Surface Particle Fields with Wind Stress and Mississippi Discharge in the Northern Gulf of Mexico. Deep Sea Research Part II: Topical Studies in Oceanography, 51, 1187-1203. https://doi.org/10.1016/S0967-0645(04)00107-9

[50] Rabalais, N.N. (2014) Physical (Hydrography), Chemical (CTD), and Biological (Water Quality) Processes of the Texas-Louisiana Continental Shelf (NCEI Accession 0161219) Version 1.1. NOAA National Centers for Environmental Information. https://ftp.nodc.noaa.gov/nodc/archive/arc0106/0161219/

[51] Pahlevan, N., Lee, Z., Wei, J., Schaaf, C.B., Schott, J.R. and Berk, A. (2014) On-Orbit Radiometric Characterization of OLI (Landsat-8) for Applications in Aquatic Remote Sensing. Remote Sensing of Environment, 154, 272-284. https://doi.org/10.1016/j.rse.2014.08.001

[52] Bailey, S.W. and Werdell, P.J. (2006) A Multi-Sensor Approach for the On-Orbit Validation of Ocean Color Satellite Data Products. Remote Sensing of Environment, 102, 12-23. https://doi.org/10.1016/j.rse.2006.01.015

[53] Lee, Z., Mannino, A., Muller-Karger, F.E., Ondrusek, M. and Salisbury, J. (2013) GEO-CAPE, GOMEX 2013. SeaWiFS Bio-Optical Archive and Storage System (SeaBASS). NASA. https://seabass.gsfc.nasa.gov/cruise/gomex_2013

[54] Rabalais, N.N. (2012) Physical (Hydrography), Chemical (CTD), and Biological (Water Quality) Processes of the Texas-Louisiana Continental Shelf (NCEI Accession 0162101) Version 1.1. NOAA National Centers for Environmental Information. http://ftp.nodc.noaa.gov/nodc/archive/arc0106/0162101/

[55] Rabalais, N.N. (2013) Physical (Hydrography), Chemical (CTD), and Biological (Water Quality) Processes of the Texas-Louisiana Continental Shelf, 2013 (NCEI Accession 0162440) Version 1.1. NOAA National Centers for Environmental Information. http://ftp.nodc.noaa.gov/nodc/archive/arc0107/0162440/

[56] Willmott, C.J. (1981) On the Validation of Models. Physical Geography, 2, 184-194.

[57] Wang, M. and Shi, W. (2012) Sensor Noise Effects of the SWIR Bands on MODISDerived Ocean Color Products. IEEE Transactions on Geoscience and Remote Sensing, 50, 3280-3292. https://doi.org/10.1109/TGRS.2012.2183376

[58] Bailey, S.W., Franz, B.A. and Werdell, P.J. (2010) Estimation of Near-Infrared Water-Leaving Reflectance for Satellite Ocean Color Data Processing. Optics Express, 18, 7521-7527. https://doi.org/10.1364/OE.18.007521

[59] Chaichitehrani, N. (2018) Numerical Experiment of Sediment Dynamics over a Dredged Pit on the Louisiana Shelf. PhD Thesis, Louisiana State University, Louisiana. 